\title{
Investigation of Friedel-Crafts Alkylation in the Presence of Supported Sulfonic Acid on Silica Gel
}

\author{
A. R. KIASAT ${ }^{1}$, M. KARIMI-CHESHMEALI ${ }^{2}$, \\ R. SOLEYMANI ${ }^{3 *}$, AND H. RAJABZADEH ${ }^{4}$ \\ ${ }^{1}$ Department of Chemistry \\ Shahid Chamran University, Ahvaz, Iran \\ ${ }^{2}$ Department of Chemistry, Omidiyeh Branch \\ Islamic Azad University, Omidiyeh, Iran \\ ${ }^{3}$ Young Researchers Club, Shahre Rey Branch \\ Islamic Azad University, Tehran, Iran \\ ${ }^{4}$ Department of Chemistry, Dezful Branch \\ Islamic Azad University, Dezful, Iran \\ nima_soleimany@yahoo.com
}

Received 11 August 2011; Accepted 26 October 2011

\begin{abstract}
From the Reaction between cellulose and chloro sulfonic acid was prepared sulfuric acid cellulose composition as a new solid acid. The solid acid supported on silica gel and then as an effective catalyst in Friedel-Crafts alkylation of alcohols and aromatic compounds was used. The reaction progress was controlled using thin layer chromatography and the reaction products were analyzed using IR spectroscopy devise. The results show this new catalyst is effective in the friedel crafts alkylation and C-C bond formation was done in short time with very good yields.
\end{abstract}

Keywords: Catalyst, Cellulose sulfuric acid, Friedel-Crafts alkylation, Silica gel.

\section{Introduction}

Catalysts are compounds that can speed up chemical reactions, but they do not participate in it. From Different types of catalysts can be named acidic catalyst that would have used a lot in many chemical reactions. These compounds have many applications in various chemical reactions ${ }^{1-7}$. The acid catalyst that is commonly used, are based on acids such as $\mathrm{HF}, \mathrm{H}_{2} \mathrm{SO}_{4}$, $\mathrm{HCLO}_{4}, \mathrm{H}_{3} \mathrm{PO}_{4}$. The solid acids have some advantages such as easy operation; reduce corrosion and easy disposal ${ }^{8-15}$. Also, the development of cleaner synthetic methods, reducing waste and by-products, or stop making them, in addition to cost effectiveness that help to human in order to clean the environment, are its benefits of these catalysts ${ }^{12-14}$. Currently, hundreds of industrial processes use the solid acids such as zeolites mixed oxides containing heteropoly acids and phosphates ${ }^{13,14}$. Catalyzed reactions due to high selectivity in chemical processes are superior relative to stoichiometry material. The organic 
compounds are divided to two categories, the aliphatic and aromatic compound. The aromatic compounds have high degree of unsaturated and they can be as a source of electrons for electrophilic attack. The reaction of aromatic compounds with electrophils, such as nitrogen, sulfure and halogen is an electrophilic substitution reaction. Alkylation and acylation reactions are the most important of aromatic substitution reactions ${ }^{15-17}$. Charles Friedel and James Crafts presented a report about the carbon - carbon formation and carbonic skeleton increasing of reacted benzene with 2-chloro propane in the presence of aluminum chloride in the 1877. The importance of this reaction is due to formation of carbon - carbon bond and increasing of carbonic skull in these compounds ${ }^{18-20}$. FriedelCrafts alkylation is one of the important methods of alkylation. In this reaction an alkyl group will be added to the aromatic compound in the presence of a catalyst and new C-C bond is formed ${ }^{15-17}$. Common methods of Friedel - Crafts alkylation are: a) alkylation using alkyl halide in the presence of Lewis acid, b) alkylation using an alkene in the present of Lewis acid, c) alkylation using an alcohol in the present of lewis acid ${ }^{21}$. The mechanism of electrophilic substitution reaction begins with the formation of carbocation (I) and then an aromatic compound attack to carbocation as a nucleophile and arenium ion is formed, arenium ion with the loss of a proton is changed to benzene alkyl ${ }^{21}$.

It is noteworthy that the reaction of Friedel-Crafts is done in the presence of Lewis acids. Therefore, each agent in the environment that produces carbocation, is causing reactions Friedel-Craft to be done. Alcohols in an acidic environment are more willing to do for the carbocation formation and Friedel-Craft alkylation with aromatic compounds. Problems such as corrosion and the transportation is causing many problems for using in industrial applications. For this purpose the solid acid is used to replace. But the main reason for the use of solid acids is that these compounds have too much acidic character. These compounds are highly compatible in environment and as safe and nontoxic compounds have hydroxyl number of first and second type that it causing they are easily converted to sulfonic acid. Studies in the field of silica sulfuric acid were done by M.A.Zolfigol in 2001. This solid acid as a mineral solid acid is highly acidic character. Silica sulfuric acid is prepared from the reaction between chlorosulfonic acid and silica without the use of solvents under inert gas ${ }^{22}$ (Figure 1).

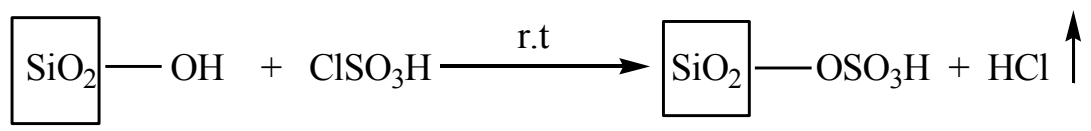

Figure 1. Common methods illustration of Friedel-Crafts alkylation.

The other mechanism, silica is produced from a reaction between a meta acid-alkaline and acid. This is usually done by passing carbon dioxide gas into sodium meta silicate diluted solution. Usually this solution is conversed to a gel and $\mathrm{Na}$ ions are washed and dried. Silanol groups are condensed and they form the polymer siloxane, this act creates an amorphous material consisting of spherical particles consisting of $\mathrm{SiO}_{4}$ groups irregularly. Applications of silica gel are due to its surface characters and depend on the distribution and nature of hydroxyl groups on the surface ${ }^{23-41}$. Various techniques such as NMR, IR, Raman, and chemical experiments have been used to determine the silica structure. The results obtained show that $\mathrm{OH}$ groups present in silica surface. This compound was studied in various mechanisms such as phenols nitration, de-protection of tri methyl silyl ether, the epoxy ring opening, oxidation of alcohol, aldol ketone condensation and the other reactions as a catalyst ${ }^{23-41}$. 


\section{Experimental}

Raw materials purchased for the reaction from Merck and were used without any purification. The reaction progress was followed using TLC thin layer chromatography. The reaction product was determined using IR spectroscopy. The whole process was done using TLC-Card Silica Gel - G/UV $254 \mathrm{~nm}$, analytical balance Mitller/Colleg 150, OVEN/Model: U30/W:800-Shimaz CO, FT-IR: Spectrometer - Spectrum RX 1 perkin Elmer AVE $\left(4000-400 \mathrm{~cm}^{-1}\right), \mathrm{pH}$ meter: Horiba model:f-IIE. The reaction is as follows:

\section{Preparation of Stabilized Sulfonic Acid on Silica Gel}

Cellulose and carbon tetrachloride have transferred to an Erlenmeyer flask with two openings and Meyer had put on a magnetic mixer. Then we added chloroSulfonic acid and carbon tetrachloride to drip into the Erlenmeyer flask containing cellulose and carbon tetrachloride. Also we did the reaction under the vacuum circumstance in order to expedite the removal of $\mathrm{HCl}$ gas and prevent moisture absorption by the obtained catalyst (Figure 2).

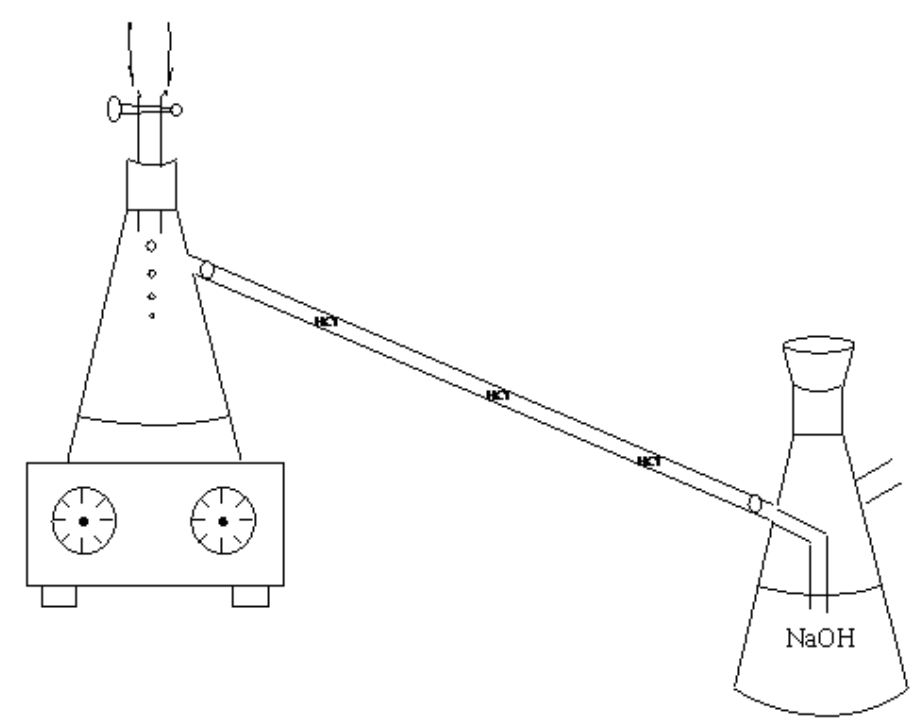

Figure 2. Demonstration of Friedel-Crafts reaction in the presence of Lewis acid.

Obtained Cellulose sulfonic acid product is as a gel and it is difficult to work it. We added silica gel to be a homogeneous black powder (Figure 3).

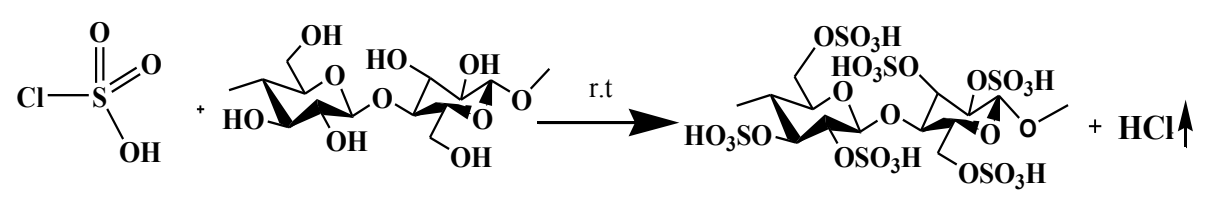

Figure 3. The reaction of chlorosulfonic acid and silica gel in presence of inert gas. 
Acidic Capacity Determination of Stabilized Sulfonic Acid Cellulose on Silica Gel by Titration

Suspension of $1 \mathrm{~g}$ of solid acid in $25 \mathrm{~mL}$ of distilled water was prepared and it was titrated with Soda solution $0.1 \mathrm{M}$ in the presence of phenolphthalein. $66 \mathrm{ml}$ was used to achieve eq point. Thus, the acid capacity is $6 / 6 \mathrm{mmol}$ per gram of acid and the $\mathrm{pH}$ of solution is 1.22 using $\mathrm{pH}$ meter.

\section{Optimize the Reaction Conditions}

To get the best reaction conditions, $1 \mathrm{mmol}(138 / 0 \mathrm{~g})$ para methoxy banzyl alcohol and $3 \mathrm{~mL}$ of benzene as initial materials with different amounts of weight stabilized cellulose sulfonic acid on silica gel (05/0-5) were mixed and the reaction was done in reflux condition. The Reaction progress was followed by thin layer chromatography (TLC) and nhexane- ether $(2: 8)$ in the tank.

The Method of Alcohol Alkylation and Numerous Aromatic Compounds in the Presence of Supported Sulfonic Acid on Silica Gel

Amount of alcohol and aromatic compounds (benzene, toluene and ortho Dichloro benzene) with $1: 3$ ratio with $0.1 \mathrm{~g}$ of stabilized cellulose sulfonic acid on silica gel was poured into a $25 \mathrm{ml}$ balloon and the reaction mixture was placed under reflux. The Reaction progress was followed by thin layer chromatography (TLC) and n-hexane-ether (2:8) in the tank. After completing the reaction, the reaction mixture was filtered. Solvent mixture by calcium chloride was dehydrated and then was filtered. Finally, it was vaporized by rotary and the products extracted with the different yield.

\section{Results and Discussion}

After the initial reaction, products were obtained with yields between 73 to 92 percent. To identify the reaction products in addition to following up with chromatography TLC thin layer was used IR spectroscopy. In alcohol structure, existence of broad and index peak at $3000 \mathrm{~cm}^{-1}$ related to $\mathrm{OH}$ group is evident and with the end of the reaction peak gradually disappears. Also we did not use ${ }^{1} \mathrm{H}-\mathrm{NMR}$ spectroscopy to identify products.

The ortho and para hydrogen in the ${ }^{1} \mathrm{H}-\mathrm{NMR}$ spectrum was not easily identifiable because the studied compound structure has a low polarity. The results and identified products are reported in Table 1. Comparing the results shows that replacement of a substitute on the benzene ring in alcohol, carbocation intermediate, is stable and the reaction rate increases (Figure 4).

Table 1. The results related to Friedel-Crafts reaction of alcoholic and aromatic structure in the presence of supported acid on silica gel.

Substrates $\begin{gathered}\text { Aromatic } \\ \text { structure }\end{gathered}$


3<smiles>COc1ccc(CO)cc1</smiles>

4<smiles>COc1ccc(CO)cc1</smiles>

5<smiles>CC(C)(C)c1ccc(CO)cc1</smiles>

6<smiles>CC(C)(C)c1ccc(CO)cc1</smiles>

7<smiles>CC(C)(C)c1ccc(CO)cc1</smiles>

8<smiles>CC(C)(C)c1ccc(CO)cc1</smiles>

9<smiles>OCc1ccccc1</smiles>

10<smiles>OCc1ccccc1</smiles>

11<smiles>OCc1ccccc1</smiles><smiles>Cc1ccc(C)cc1</smiles><smiles>Clc1ccccc1Cl</smiles><smiles>c1ccccc1</smiles>
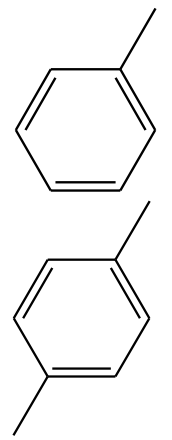<smiles>Clc1ccccc1Cl</smiles><smiles>c1ccccc1</smiles><smiles>Cc1ccc(C)c(Cc2ccc(O)cc2)c1</smiles><smiles>COc1ccc(Cc2ccc(Cl)c(Cl)c2)cc1</smiles><smiles>CC(=O)c1ccc(Cc2ccccc2)cc1</smiles>

$\left(\mathrm{H}_{3} \mathrm{C}\right)_{3} \mathrm{C}$

$15 \quad 85$<smiles>Cc1ccc(C)c(Cc2ccc(C(C)(C)C)cc2)c1</smiles><smiles>CC(C)(C)c1ccc(Cc2ccc(Cl)c(Cl)c2)cc1</smiles><smiles>c1ccc(Cc2ccccc2)cc1</smiles>

12<smiles>Clc1ccccc1Cl</smiles><smiles>Clc1ccc(Cc2ccccc2)cc1Cl</smiles> 
13<smiles>OCc1ccc(Cl)cc1</smiles><smiles>c1ccccc1</smiles><smiles>Clc1ccc(Cc2ccccc2)cc1</smiles>

14<smiles>OCc1ccc(Cl)cc1</smiles><smiles>Cc1ccccc1</smiles><smiles>Cc1ccccc1Cc1ccc(Cl)cc1</smiles><smiles>OCc1ccc(Cl)cc1</smiles><smiles>Cc1ccc(C)cc1</smiles><smiles>Cc1ccc(C)c(Cc2ccc(Cl)cc2)c1</smiles>

$60 \quad 90$

16<smiles>OCc1ccc(Cl)cc1</smiles><smiles>Clc1ccccc1Cl</smiles><smiles>Clc1ccc(Cc2ccc(Cl)c(Cl)c2)cc1</smiles><smiles>OC1CCCC1</smiles><smiles>c1ccccc1</smiles><smiles>c1ccc(C2CCCC2)cc1</smiles><smiles>OC1CCCC1</smiles><smiles>Cc1ccccc1</smiles><smiles>Cc1ccc(C2CCCC2)cc1</smiles><smiles>OC1CCCC1</smiles><smiles>Cc1ccc(C)cc1</smiles><smiles>Cc1ccc(C)c(C2CCCC2)c1</smiles><smiles>OC1CCCC1</smiles><smiles>Clc1ccccc1Cl</smiles><smiles>Clc1ccc(C2CCCC2)cc1Cl</smiles>

21<smiles>CC(C)(C)O</smiles><smiles>c1ccccc1</smiles><smiles>CC(C)(C)c1ccccc1</smiles><smiles>CC(C)(C)O</smiles><smiles>Cc1ccccc1</smiles><smiles>Cc1ccc(C(C)(C)C)cc1</smiles><smiles>CC(C)(C)O</smiles><smiles>Cc1ccc(C)cc1</smiles><smiles>Cc1ccc(C)c(C(C)(C)C)c1</smiles> 
24<smiles>CC(C)(C)O</smiles><smiles>Clc1ccccc1Cl</smiles><smiles>CC(C)(C)c1ccc(Cl)c(Cl)c1</smiles><smiles>CCC(O)c1ccccc1</smiles><smiles>c1ccccc1</smiles><smiles>CCC(c1ccccc1)c1ccccc1</smiles>

60 84 26<smiles>CCC(O)c1ccccc1</smiles><smiles>Cc1ccccc1</smiles><smiles>CCC(c1ccccc1)c1cccc(C)c1</smiles><smiles>CCC(O)c1ccccc1</smiles><smiles>Cc1ccc(C)cc1</smiles><smiles>CCC(c1ccccc1)c1cc(C)ccc1C</smiles><smiles>CCC(O)c1ccccc1</smiles><smiles>Clc1ccccc1Cl</smiles><smiles>CCC(c1ccccc1)c1ccc(Cl)c(Cl)c1</smiles>

29<smiles>O=[N+]([O-])c1cccc(CO)c1</smiles><smiles>c1ccccc1</smiles><smiles>COc1cccc(Cc2ccccc2)c1</smiles>

$30 \quad 90$

30<smiles>O=C(O)c1cccc(CO)c1</smiles><smiles>Cc1ccccc1</smiles><smiles>COc1cccc(Cc2cccc(C)c2)c1</smiles>

31<smiles>COc1cccc(CO)c1</smiles><smiles>Cc1ccc(C)cc1</smiles><smiles>COc1cccc(Cc2cc(C)ccc2C)c1</smiles>

32<smiles>Clc1ccccc1Cl</smiles><smiles>COc1cccc(Cc2ccc(Cl)c(Cl)c2)c1</smiles> 

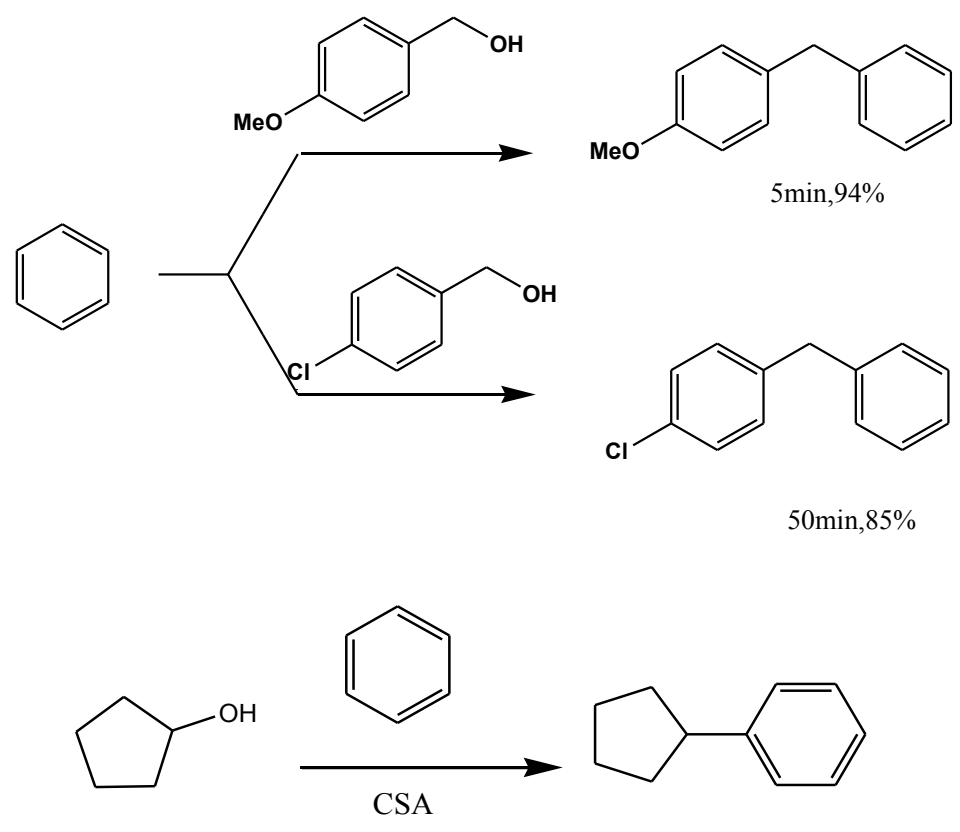

$105 \mathrm{~min}, 80 \%$<smiles>CC(C)(C)O</smiles><smiles>Cc1ccccc1</smiles><smiles>CC(C)(C)c1ccccc1</smiles>

$60 \mathrm{~min}, 78 \%$

Figure 4. Preparation schematic of supported sulfonic acid on silica gel.

According to the result, groups that are causing instability carbocation, reduce reaction rate. To confirm this effect, para nitro benzene alcohol reacts fridel-crafts with benzene. The results show that the reaction rate sharply decreased and the reaction was not complete even after 360 minutes (Figure 5).

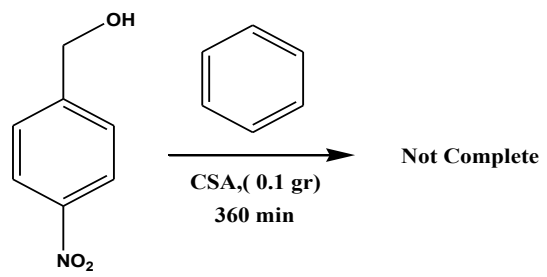

Figure 5. The mechanism of preparation of supported sulfonic acid on silica gel.

$1 \mathrm{mM}$ of various alcohols with $3 \mathrm{ml}$ of toluene was provided. Methyl substituted is electron donor and activator of benzene ring in electrophilic substitution reaction. It is expected that the reaction rate increases. The results is given at Table 1 . The reaction rate of toluene is more than benzene (Figure 6). 


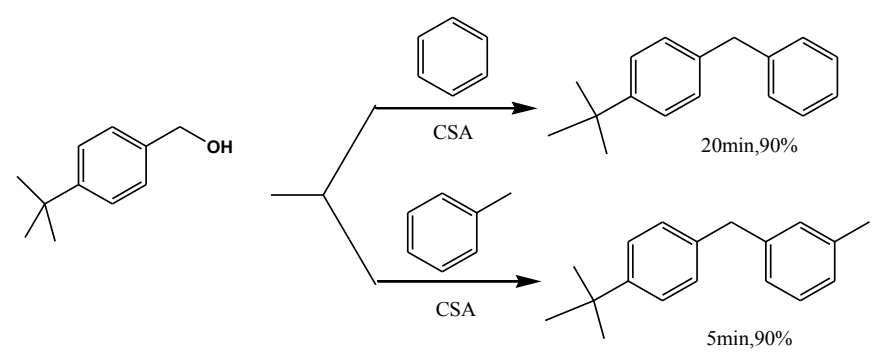

Figure 6. The mechanism of alcohols Friedel-Crafts alkylation reaction with benzene in the presence of supported cellulose sulfonic acid on silica gel.

Para xylene aromatic compound was selected as a aromatic ring and Friedel- Crafts alkylation of this compound was performed with the various alcohol at the presence of cellulose sulfonic acid (Table 1).

The effect of electron donor and recipient substituted groups on the benzene ring of ortho chloro benzene was studied. Halogens are known as a weak inactivate substitute and director of ortho and para position. $1 \mathrm{mM}$ of various alcohols with $3 \mathrm{~mL}$ of benzene ortho chlorine was mixed and refluxed at the presence of $0.1 \mathrm{~g}$ supported cellulose sulfonic acid on silica gel. Halide groups inactivate the rings against substitute reactions and reduce the reaction rate (Figure 7).

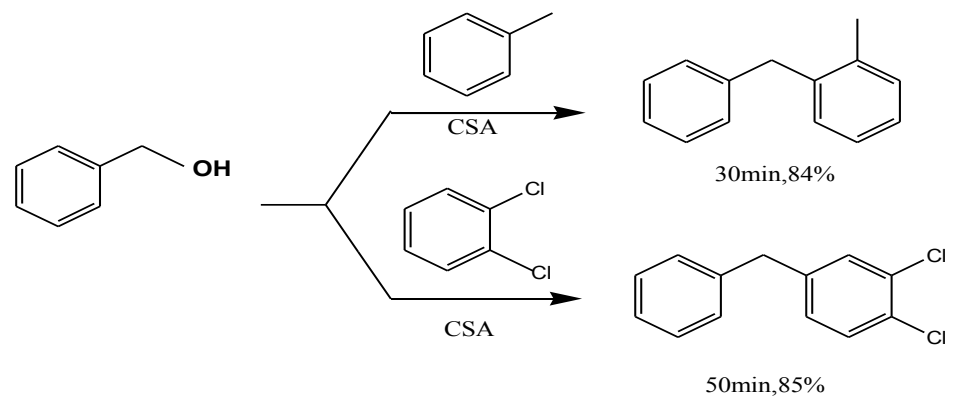

Figure 7. Demonstration of Friedel-Crafts alkylation reaction with benzene in the presence of supported cellulose sulfonic acid on silica gel.

\section{Conclusion}

The results showed that the mechanism of solid cellulose sulfonic acid has higher efficiency than hydrochloric acid and the elimination of sulfonic acid and replacement of hydrochloric acid, risks and problems in the mechanism of cellulose is less. Also unlike other catalysts, cellulose sulfonic acid catalyst is easily removed from the system. The preparation of cellulose Sulfonic acid catalysts will be easier, faster and cheaper than the other catalysts. The separation and purification products do not require a complicated process. Finally. This catalyst will be as The solid acid catalyst environmentally friendly. The catalytic reaction of Friedel -Crafts would be very salient.

\section{Acknowledgment}

This work was supported by Islamic Azad University Shahre-rey branch, Shahid Chamran University, Islamic Azad University Omidie branch and Islamic Azad University Dezful branch. 


\section{References}

1. Tamami B, Goudarzian. N and Kiasat A.R, Eur Polym J., 1997, 33 , 977.

2. Tamami. B and Kiasat A.R, Iranian Polym J., 1997, 6 ,4.

3. Kiasat A.R and Sayyahi S, Catalysis Commun., 2010, 11, 484.

4. Rajabzadeh H, Nourouzian D, Hadi Alijanvand H, Divsalar A, Badraghi J, Barzegar A, Monajjemi. M, Zare. K, Sheibani. N, Saboury A A and Moosavi Movahedi A A, $J$ Iran Chem Soc., 2011, 8, 553.

5. Tazikeh Lemeski. E, Rezaei Behbehani G, Saboury A A, Monajjemi M, Zafar Mehrabian R, Ahmadi Golsefidi M, Rajabzadeh. H, Baei M T and Hasanzadeh S, $J$ Solution Chem., 2011, 40, 575.

6. Kiasat A R, Badri R and Sayyahi S, Chin Chem Lett., 2008, 19, 1301.

7. Kiasat. A.R and Yahyavi. H, Microchim Acta, 2010, 170, 135.

8. Pourreza N, Zolgharnein J, Kiasat A R and Dastyar. T, Talanta, 2010, 81, 773.

9. Pourreza N, Parham H, Kiasat A R, Ghanemi. K and Abdollahi N, Talanta, 2009, 78, 1293.

10. Armor J N, Apple Catal A Gen., 2001, 222, 407.

11. Namba S and Hosonuma T, J Catal., 1981, 72, 16.

12. Merrifield R B, J Am Chem Soc., 1963, 85, 2149.

13. Armor J N, Appl Catal.A Gen., 1999, 189, 153.

14. Farrouto R J and Heck R M, Catal Today, 2000, 55,179.

15. Olah G A, Friedel-Crafts \& Related Reaction, Wiley Interscience, New York and London, 1963.

16. McMurry J, Org Chem., $7^{\text {th }}$ Ed., 2008.

17. Olah G A, Friedel-Crafts Chemistry, Wiley and Sons, New York, 1973.

18. Chuang I S and Maciel G E, J Am Chem Soc., 1996, 118, 401.

19. Pesck. J. Joseph and Matyska M T, Chemically Modified Surfaces, Royal Socity of Chemistry, 1996.

20. Clark J H, Catalysis of Organic Reactions by Supported Inorganic Reagents, 1996.

21. Norris J F and Sturgis B M, J Am Chem Soc., 1939, 61, 1413.

22. Zolfigol M A, Tetahedron., 2001, 57, 9509.

23. Izumi Y and Natsume N, Bull Chem Soc Jpn., 1989, 62, 2159.

24. Shimizu K, Niimi K and Satsuma A, Appl Catal A, 2008, 349 ,1.

25. Albar H A, Khalaf A and Bahaffi S, J Chem Res (S), 1997, 20, 165.

26. James B, Suresh E and Naira M S, Tetrahedron Lett., 2007, 48, 6059.

27. Liu Y H, Liu Q S and Zhang Z H, Tetrahedron Lett., 2009, 50, 916.

28. Choudary B M, Bhavnari P C, Catal Commun., 2002, 3, 363.

29. Xiao Y and Malhotra S V, J Mol Cat A, 2005, 230, 129.

30. Mantri. K, Komura. K, Kubota Y and Sugi Y, J Mol Catal A., 2005, 236, 168.

31. Singh R P, Kamble R M, Chandra K L, Saravanan P and Singh V K, Tetrahedron, 2001, 57, 241

32. Shiina I and Suzuki M, Tetrahedron. Lett., 2002, 43, 6391.

33. Shiina I, Suzuki M and Yokoyama K, Tetrahedron Lett., 2002, 43, 6395.

34. Zou X, Wang X, Cheng C, Kong L and Mao H, Tetrahedron Lett., 2006, 47, 3767.

35. Deshmukh A P, Padiya K J and Salunkhe M M, J Chem Res (S), 1999, $32,568$.

36. Gondos. G, Dombi G, Montash Chem., 2002, 133, 1279.

37. Ramachary D B, Reddy G B, Mondal R, Tetrahedron Lett., 2007, 48, 7618.

38. Zhao J L, Liu. L, Gu C L, Wang D and Chen Y J, Tetrahedron Lett., 2008, 49, 1476.

39. Kantam. M L, Laha S, Yadav J and Sreedhar B, Tetrahedron Lett., 2006, 47, 6213.

40. Singh. P K, Bisai. A and Singh. V K, Tetrahedron Lett., 2007, 48, 1127.

41. Zhou. J L, Ye M.C, Sun X L and Tang Y, Tetrahedron, 2009, 65, 6877. 


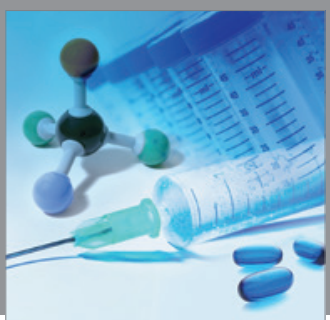

International Journal of

Medicinal Chemistry

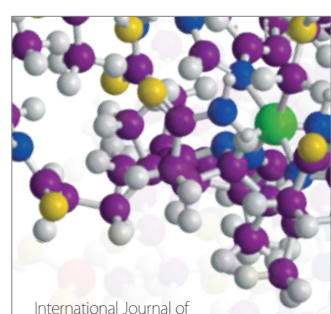

Carbohydrate Chemistry

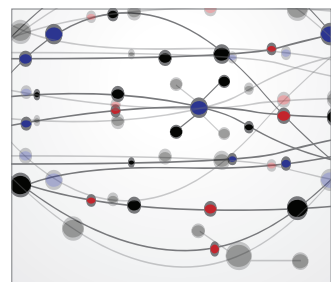

The Scientific World Journal
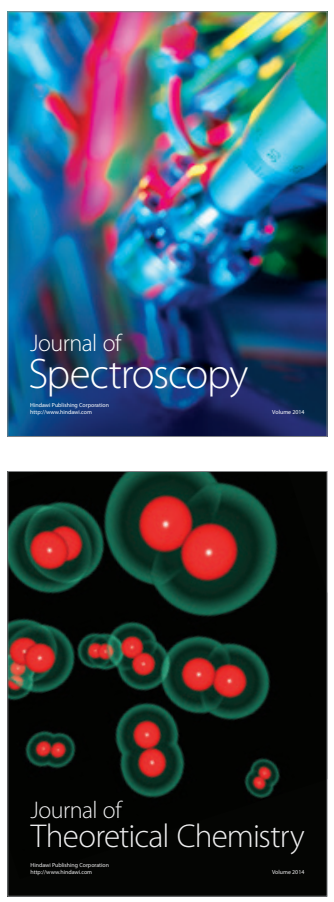
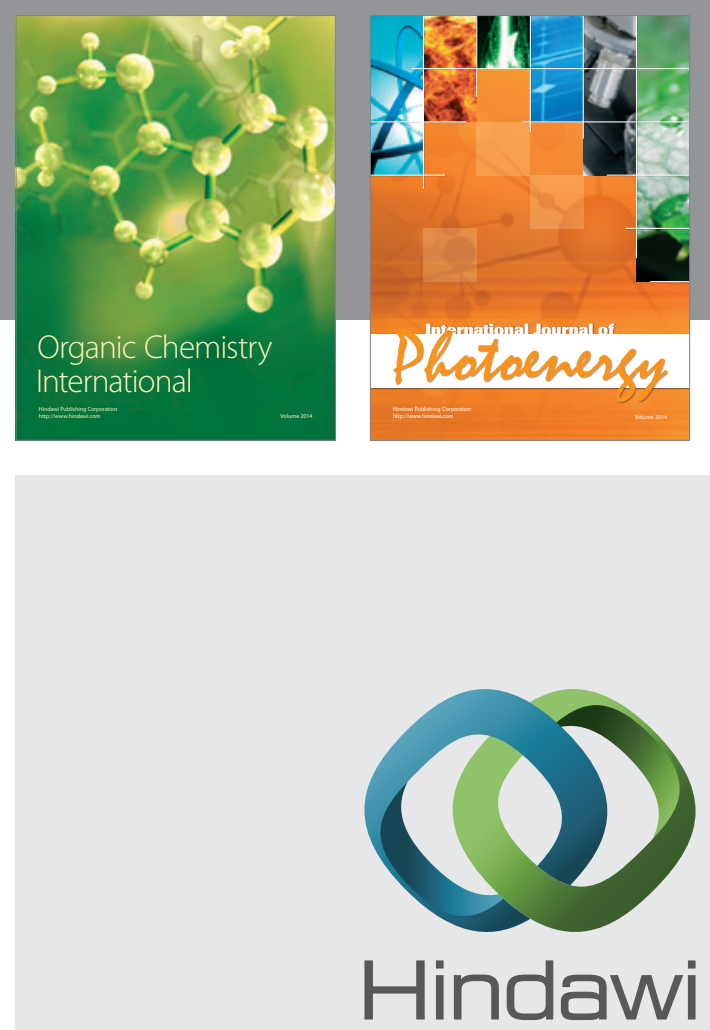

Submit your manuscripts at

http://www.hindawi.com
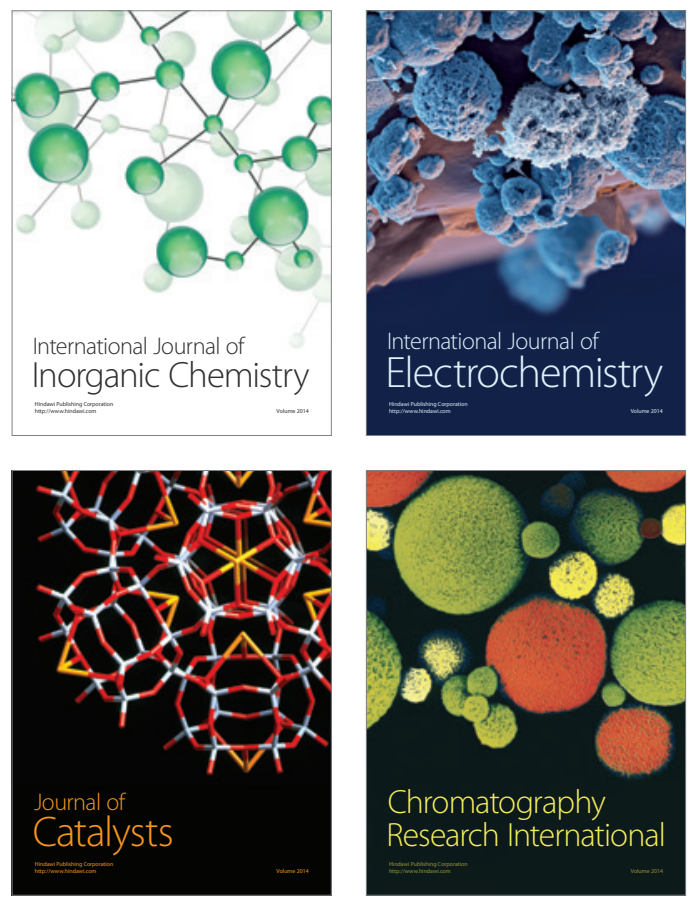
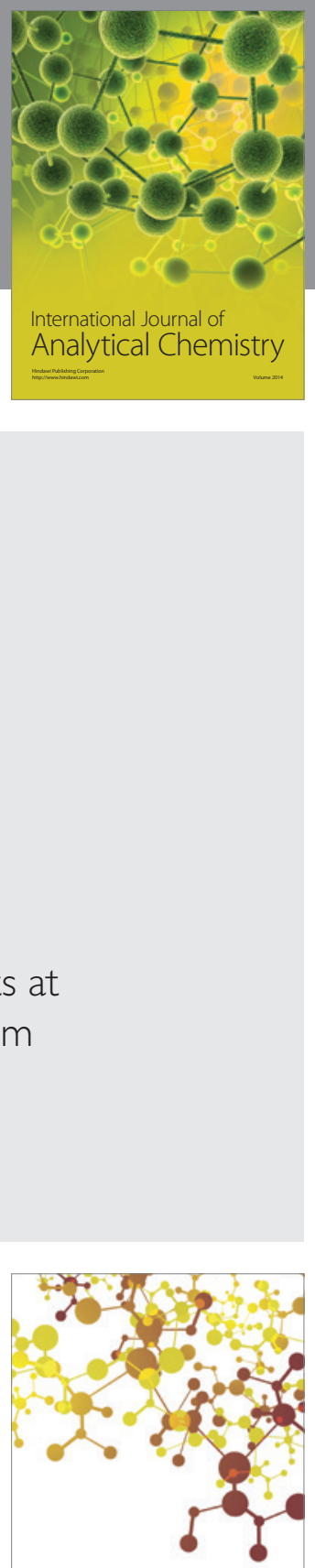

Journal of

Applied Chemistry
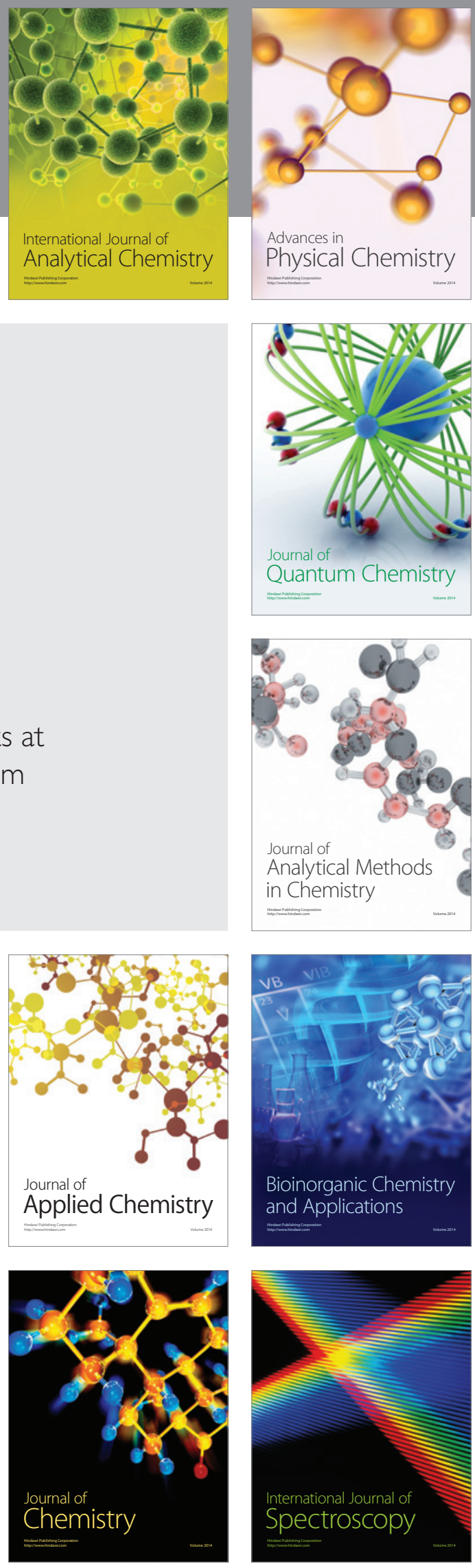